\title{
IN-DEPTH CHARACTERIZATION OF CELLULOSIC PULPS FROM OIL PALM EMPTY FRUIT BUNCHES AND KENAF CORE, DISSOLUTION AND PREPARATION OF CELLULOSE MEMBRANES
}

\author{
SHARIFAH NURUL AIN SYED HASHIM, ${ }^{*}$ BALQIS AZ-ZAHRAA NORIZAN, ${ }^{*}$ \\ KHAIRUNNISA WAZNAH BAHARIN, SARANI ZAKARIA, CHIN HUA CHIA, \\ ANTJE POTTHAST, ${ }^{* *}$ SONJA SCHIEHSER, ${ }^{* *}$ MARKUS BACHER, ${ }^{* *}$ THOMAS ROSENAU ${ }^{* * * * * *}$ \\ and SHARIFAH NABIHAH SYED JAAFAR" \\ "Bioresources and Biorefinery Laboratory, Faculty of Science and Technology, Universiti Kebangsaan \\ Malaysia, 43600 UKM Bangi, Selangor, Malaysia \\ *** Division of Chemistry of Renewable Resources, Department of Chemistry, University of Natural Resources \\ and Life Sciences, Vienna, Muthgasse 18, A-1190 Vienna, Austria \\ *** Johan Gadolin Process Chemistry Centre, Ảbo Akademi University, Porthansgatan 3, \\ Åbo/Turku FI-20500, Finland \\ ¿ Corresponding author: Sharifah Nabihah Syed Jaafar, nabihah@ukm.edu.my
}

Received April 21, 2020

Cellulosic pulps from oil palm empty fruit bunches (EFB) and kenaf core were bleached and characterized with regard to their sugar content, crystallinity, molecular weight, carboxyl group content and solubility in NaOH/urea. The sugar content results showed glucose, mannose and xylose in EFB pulp and only glucose and xylose in the kenaf core cellulosic pulp. The crystallinity indexes of EFB cellulosic pulp and the kenaf core cellulosic pulp were 49 and $51 \%$, respectively. The carboxyl group content of EFB cellulosic pulp was lower than that of kenaf core pulp. However, the molecular weight of EFB cellulose pulp was higher than that of kenaf core pulp. Because the solubility of kenaf core pulp was higher and acceptable, it was successful in forming a cellulose membrane (CM). The CM was cast at two different thicknesses: $0.04 \mathrm{~mm}$ and $0.07 \mathrm{~mm}$. CM0.07 had smaller pore sizes, which yielded a higher tensile strength than CM0.04.

Keywords: bleaching, CP-MAS NMR, crystallinity, pore size, SEC-MALLS

\section{INTRODUCTION}

Lignocellulosic material is a natural polymer, such as cellulose, hemicellulose and lignin. These materials are renewable, biocompatible and biodegradable. Among these three constituents, cellulose is the most available natural polymer on earth. Cellulose shows great potential for the fabrication of value-added materials, to replace fossil-based materials, ${ }^{1}$ due to its natural strength, especially flexural strength. Eventually, the lignin needs to be removed to obtain highly pure cellulose pulp. The delignification process involves pulping and bleaching procedures. The combination of these processes can produce a variety of pulp purity grades, depending on the type of plant used and the pulping/bleaching processes. $^{2,3}$ The potential application and utilization options of the resulting pulps in follow-up processes, e.g. papermaking, textiles and membranes, are based on their quality and properties after delignification.

Cellulose is a semi-crystalline and highmolecular-weight polymer. Cellulose has primary hydroxyl groups at C-6 of each anhydroglucose unit (AGU) and secondary hydroxyl groups at $\mathrm{C}-2$ and $\mathrm{C}-3$, which create very strong intra- and intermolecular hydrogen bonds. This hydrogenbond network renders cellulose hard to dissolve. Crystallinity in cellulose can be determined using $\mathrm{X}$-ray diffraction, ${ }^{4}$ cross-polarization magic angle spinning nuclear magnetic resonance (CP-MAS NMR) ${ }^{5}$ and Fourier-transform infrared spectroscopy. ${ }^{6}$ The molecular weight of cellulose can be determined by end-group titration, osmometry, sedimentation velocity, capillary 
viscometer, light scattering or size exclusion chromatography (SEC), which is currently the method of choice. ${ }^{7}$ The average molecular weight is given either as number average molecular weight $\left(\mathrm{M}_{\mathrm{n}}\right)$, z-average molecular weight $\left(\mathrm{M}_{\mathrm{z}}\right)$, weight average molecular weight $\left(\mathrm{M}_{\mathrm{w}}\right)$ or as viscosity average molecular weight $\left(\mathrm{M}_{\mathrm{v}}\right)$.

Cellulose membranes (CMs) can be produced from cellulose type II, by regeneration from cellulose solution. CMs are frequently employed for separation in membrane technology due to their porous structure. The pore size and its distribution depend on the type of coagulant and coagulation parameters. ${ }^{8-10}$ Owing to their porous structure, CMs have the potential to be used as transparent and printable films by incorporation with polyvinyl alcohol. ${ }^{11}$ The introduction of materials, such as graphene oxide (GO), ${ }^{12}$ titanium dioxide $\left(\mathrm{TiO}_{2}\right)^{13}$ and bentonite ${ }^{14}$ particles, into the $\mathrm{CM}$ porous structure enhanced its permeability, electrical and antibacterial properties. The findings indicated that the introduction of $\mathrm{GO}$ and bentonite increased the pore size of the composites, while the incorporation of $\mathrm{TiO}_{2}$ showed opposite results. First, CM with $0.005 \mathrm{wt} \%$ of GO exhibited a uniform pore size $(0.9 \mathrm{~nm})$, and consequently, led to high permeability $\left(13.65 \mathrm{~L} \mathrm{~m}^{2} \mathrm{~h}^{-1}\right)$ and low salt rejection $(15.82 \%)$. Second, $6 \mathrm{wt} \% \mathrm{TiO}_{2}$-filled $\mathrm{CM}$ composite had the lowest pore size, ranging from 0.14 to $1 \mu \mathrm{m}$, and the highest zeta potential of $16.19 \mathrm{mV}$. The incorporation of $3 \%$ bentonite caused an increase in the interlayer distance to $1.71 \mathrm{~nm}$ with a tensile strength of $150 \mathrm{MPa}$.

In Malaysia, palm oil and kenaf are plantbased commodities with an estimated annual production of more than $5 \mathrm{MnT} \mathrm{ha}^{-1}$ and $11 \mathrm{Tn}$ $\mathrm{ha}^{-1}$, respectively. Oil palm and kenaf plantations generate abundant wastes, such as oil palm empty fruit bunches (EFBs) and kenaf cores, respectively; these waste products are composed of approximately 34 to $37 \%$ cellulose. ${ }^{15,16}$ In this study, we investigated the chemical and physical properties of EFB and kenaf core pulps before proceeding with membrane preparation. The reason we used two types of pulps is to confirm and compare the pulp properties. This study focuses not only on utilizing waste biomass, but also on the development of value-added products.

\section{EXPERIMENTAL \\ Materials}

Oil palm EFB pulp sheets were purchased from Eko Pulp \& Paper Sdn. Bhd., and kenaf core pulp was obtained from the Forest Research Institute Malaysia. The sodium chlorite $\left(\mathrm{NaClO}_{2}\right)$, glacial acetic acid $\left(\mathrm{CH}_{3} \mathrm{COOH}\right)$, sodium hydroxide $(\mathrm{NaOH})$, urea, $95-98 \%$ sulfuric acid, 37\% hydrochloric acid $(\mathrm{HCl})$, methanol $\left(\mathrm{CH}_{3} \mathrm{OH}\right)$, ethanol $\left(\mathrm{C}_{2} \mathrm{H}_{5} \mathrm{OH}\right), \mathrm{N}, \mathrm{N}$-dimethylacetamide (DMAc), $\quad 9 H$-fluoren-2-yl-diazomethane (FDAM) solution and lithium chloride $(\mathrm{LiCl})$ pyridine, 4dimethylaminopyridine, $\quad \mathrm{N}, \mathrm{O}$-bistrifluoroacetamide, trimethylsilyl chloride and ethyl acetate employed in this study were of analytical grade, purchased from commercial sources and utilized as received.

\section{Bleaching procedure}

Oven-dried, disintegrated pulp was bleached via DEED treatment series, where D (first and fourth stages) comprised a chemical treatment with a mixture of $1.7 \% \mathrm{NaClO}_{2}$ and $\mathrm{pH} 4.5$ buffer solution (a mixture of $27 \mathrm{~g} \mathrm{NaOH}, 75 \mathrm{~mL} \mathrm{CH} \mathrm{COOH}_{3}$, and $925 \mathrm{~mL}$ distilled water), and $\mathrm{E}$ was a treatment with $4 \% \mathrm{NaOH}$ and $6 \%$ $\mathrm{NaOH}$ as the second and third stages, respectively. At every stage, the pulp was treated at $80{ }^{\circ} \mathrm{C}$ in a water bath for $2 \mathrm{~h}$ (D stage) and $1 \mathrm{~h}$ (E stage) and then washed with distilled water. The bleached pulp was oven-dried at $105^{\circ} \mathrm{C}$ for $24 \mathrm{~h}$ before analysis.

\section{Preparation of the membrane}

$\mathrm{NaOH} /$ urea solvent was prepared by mixing $7 \mathrm{wt} \%$ $\mathrm{NaOH}: 12 \mathrm{wt} \%$ urea: $81 \mathrm{wt} \%$ distilled water and stored overnight in the freezer. The $\mathrm{NaOH} /$ urea solvent was removed and left at room temperature until the temperature reached $-13{ }^{\circ} \mathrm{C}$. $4 \mathrm{wt} \%$ of kenaf core and EFB pulps were dissolved in the $\mathrm{NaOH} /$ urea solvent and stirred at $2300 \mathrm{rpm}$ using an overhead stirrer. The obtained cellulose solutions were centrifuged for $5 \mathrm{~min}$ at $10,000 \mathrm{rpm}$ at $5{ }^{\circ} \mathrm{C}$ to separate the dissolved and undissolved parts of the cellulose solution. The dissolved cellulose was then used for membrane fabrication with two different thicknesses $(0.04 \mathrm{~mm}$ and $0.07 \mathrm{~mm}$ ) and was subsequently coagulated in $5 \%$ $\mathrm{H}_{2} \mathrm{SO}_{4}$. The membrane samples of $0.04 \mathrm{~mm}$ thickness and $0.07 \mathrm{~mm}$ thickness were denoted as CM0.04 and CM0.07, respectively. The undissolved part was disintegrated, washed repeatedly with distilled water until neutral, and dried at $80{ }^{\circ} \mathrm{C}$ for $24 \mathrm{~h}$.

\section{Monosaccharide analysis}

The monosaccharide analyses of EFB and kenaf core pulps were conducted by immersing $2 \mathrm{mg}$ of samples in $2 \mathrm{~mL}$ of $2 \mathrm{M}$ acidic $\mathrm{CH}_{3} \mathrm{OH}$. The samples were agitated every $15 \mathrm{~min}$ to promote dissolution. After this, the samples were placed into an ultrasonic bath for $2 \mathrm{~min}$ and then were heated for $5 \mathrm{~h}$ in an oven $\left(100{ }^{\circ} \mathrm{C}\right)$. Once the samples cooled, anhydrous pyridine and sorbitol standard solution were added. The mixture was agitated and evaporated in a $\mathrm{N}_{2}$ environment. The samples were cooled to $-80{ }^{\circ} \mathrm{C}$ and freeze-dried overnight before derivatization.

Derivatization was started with the addition of 200 $\mu \mathrm{L}$ anhydrous pyridine to the freeze-dried samples. 
After incubation at room temperature for $1 \mathrm{~h}$, 4dimethylaminopyridine and $\mathrm{N}, \mathrm{O}$-bistrifluoroacetamide (with $10 \%$ trimethylsilyl chloride) were added, and the samples were stored for $2 \mathrm{~h}$ at $70{ }^{\circ} \mathrm{C}$. Thereafter, 400 $\mu \mathrm{L}$ of ethyl acetate was added before analysis with GC-FID (Agilent Technologies Model 7890B). The injection volume was $1 \mu \mathrm{L}$ at a split ratio of 10:1. An HP1 (Agilent 19091Z-413) methyl siloxane column $(30 \mathrm{~m} \times 320 \mu \mathrm{m} \times 0.25 \mu \mathrm{m})$ with $\mathrm{H}_{2}$ as carrier gas at a flow rate of $2 \mathrm{~mL} \mathrm{~min}^{-1}$ was employed for the analysis. The oven temperature was set to $140{ }^{\circ} \mathrm{C}$ for $1 \mathrm{~min}$, ramped at $4{ }^{\circ} \mathrm{C} \min ^{-1}$ to $210{ }^{\circ} \mathrm{C} \mathrm{min}^{-1}$, and then heated at $30{ }^{\circ} \mathrm{C} \mathrm{min}{ }^{-1}$ to $260{ }^{\circ} \mathrm{C} \mathrm{min}{ }^{-1}$ with a holding time of $5 \mathrm{~min}$. The temperatures of the injector and detector were retained at $260{ }^{\circ} \mathrm{C}$ and $280{ }^{\circ} \mathrm{C}$, respectively. The FID temperature was maintained at $320{ }^{\circ} \mathrm{C}$ with $\mathrm{H}_{2}$ flow at $30 \mathrm{~mL} \mathrm{~min}^{-1}$.

\section{Crystallinity index}

The solid-state NMR spectra of the wet pulps $(\sim 70$ mg) were recorded on a Bruker Avance III HD 400 spectrometer (resonance frequency for ${ }^{1} \mathrm{H} 400.13 \mathrm{MHz}$ and ${ }^{13} \mathrm{C} 100.61 \mathrm{MHz}$ ) equipped with a $4 \mathrm{~mm}$ dualbroadband CP-MAS probe. ${ }^{13} \mathrm{C}$ spectra were acquired using a total sideband suppression sequence at ambient temperature with a spinning rate of $5 \mathrm{kHz}$, crosspolarization (CP) contact time of $4 \mathrm{~ms}$, recycle delay of $2 \mathrm{~s}$, SPINAL-64 ${ }^{1} \mathrm{H}$ decoupling and acquisition time of $49 \mathrm{~ms}$. The spectral width was set to $250 \mathrm{ppm}$. Chemical shifts were referenced externally against the carbonyl signal of glycine at $\delta=176.03 \mathrm{ppm}$. The crystallinity index (CrI) was determined as the integral ratio of the crystalline and amorphous region of $\mathrm{C}-4$ based on Equation 1. ${ }^{17}$ The Dmfit program was employed to perform spectral fitting: ${ }^{18}$

$$
\operatorname{CrI}(\%)=\frac{\mathrm{A}_{86-92} \mathrm{ppm}}{\mathrm{A}_{79-92} \mathrm{ppm}} \times 100
$$

\section{Molecular weight and carboxyl group determination}

FDAM labelling, in combination with SEC, was applied to determine the molecular weight and carboxyl group content. ${ }^{19}$ For sample preparation, 20 $\mathrm{mg}$ of EFB and kenaf core pulps were suspended in 0.1 $\mathrm{M} \mathrm{HCl}$ and disintegrated for $20 \mathrm{~s}$ in a blender. The pulps were washed with $0.1 \mathrm{M} \mathrm{HCl}, 96 \% \mathrm{C}_{2} \mathrm{H}_{5} \mathrm{OH}$ and DMAc before being filtered. For labelling, the pulp was suspended in $3 \mathrm{~mL}$ of DMAc and $1 \mathrm{~mL}$ of FDAM solution. The suspension was agitated in a water bath shaker at $40{ }^{\circ} \mathrm{C}$ for 7 days. Thereafter, the filtered reaction mixture was washed with DMAc and transferred to a dry vial. A total of $1.6 \mathrm{~mL}$ of $\mathrm{DMAc} / \mathrm{LiCl}(9 \% \mathrm{~m} / \mathrm{v})$ was added to dissolve the cellulose. After it was dissolved, $0.3 \mathrm{~mL}$ of the sample was diluted with an additional $0.9 \mathrm{~mL}$ of DMAc, filtered through $0.45 \mu \mathrm{m}$ filters, and measured using SEC.
The SEC system used in this study was equipped with a multiple-angle laser light scattering (MALLS),

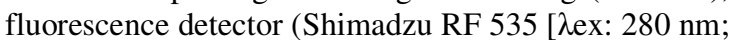

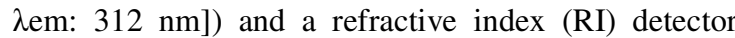
(Shodex RI-71). The SEC measurements were performed according to the following parameters: flow rate: $1.00 \mathrm{~mL} \mathrm{~min}^{-1}$; columns: four PL gel mixed ALS, $20 \mu \mathrm{m}, 7.5 \mathrm{~mm} \times 300 \mathrm{~mm}$; injection volume: $100 \mu \mathrm{L}$; run time: $45 \mathrm{~min}$; and mobile phase: $0.02 \mu \mathrm{m}$-filtered $\mathrm{DMAc} / \mathrm{LiCl}(0.9 \% \mathrm{w} / \mathrm{v})$. To determine the amount of dissolved material, an RI signal with a $\mathrm{dn} / \mathrm{dc}$ of 0.136 $\mathrm{mL} \mathrm{g} \mathrm{g}^{-1}$ and a detector constant of $5.32 \mathrm{E}^{-5} \mathrm{~V}^{-1}$ were utilized. Data evaluation was performed with Astra 4.73, GRAMS/32 and Chromeleon software, while the molecular weight distribution (MWD) was replotted using Origin software. ${ }^{20}$

\section{Solubility test}

The dissolution tests of EFB and kenaf core pulps were performed by immersing $4 \mathrm{wt} \%$ of pulp in $7 \mathrm{wt} \%$ $\mathrm{NaOH}, 12 \mathrm{wt} \%$ urea, and $81 \mathrm{wt} \%$ distilled water at -13 ${ }^{\circ} \mathrm{C}$. The pulps were stirred at $2300 \mathrm{rpm}$. The cellulose solution was centrifuged for $5 \mathrm{~min}$ at $10,000 \mathrm{rpm}$ at 5 ${ }^{\circ} \mathrm{C}$ to separate the undissolved matter. The undissolved part was disintegrated, washed repeatedly with distilled water until neutral, dried at $80{ }^{\circ} \mathrm{C}$ for $24 \mathrm{~h}$ and weighed. The solubility was calculated using Equation 2:

$$
\text { Solubility }\left(\mathrm{S}_{\mathrm{a}}\right)=\left(\frac{\mathrm{w}_{1}-\mathrm{w}_{2}}{\mathrm{w}_{1}}\right) \times 100
$$

where $\mathrm{w}_{1}$ is the initial sample weight before dissolution, and $\mathrm{w}_{2}$ is the weight of the dried insoluble residue.

\section{Morphological analysis}

The morphological analysis of the membranes was performed using a field emission-scanning electron microscope (FE-SEM Zeiss/Supra55VP) at an accelerating voltage of $3.0 \mathrm{kV}$. The membrane samples were freeze-dried before analysis. The images obtained by SEM were analysed to obtain the pore size distribution using ImageJ.

\section{Transparency and tensile test}

The transparency test was analysed using a JENWAY UV-vis 7315 spectrophotometer at a wavelength ranging from 200 to $800 \mathrm{~nm}$ under vacuum. The membrane samples were air-dried and cut to $1 \mathrm{~cm} \times 4 \mathrm{~cm}$. The tensile test of the membranes was carried out according to ASTM D882, using a tensile machine (GOTECH model Al-3000), with a 1

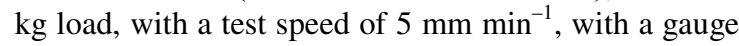
length of $30 \mathrm{~mm}$. The samples were air-dried for $24 \mathrm{~h}$ and cut into five pieces with dimensions of $6 \mathrm{~cm} \times 1$ $\mathrm{cm}$. 


\section{RESULTS AND DISCUSSION \\ Monosaccharide composition}

Table 1 shows the monosaccharide composition of EFB and kenaf core pulps. Although both types of pulps contained xylose and glucose, their concentrations were higher in EFB. Xylose is the main monosaccharide unit in xylan hemicellulose. This finding revealed that both pulps have xylan as a hemicellulose component. ${ }^{21}$ A small amount of mannose was detected only in EFB pulp $\left(1.39 \mu \mathrm{g} \mathrm{mg}^{-1}\right)$; this result is consistent with previous findings. ${ }^{22}$ The remaining hemicellulose in the pulp was not completely removed from cellulose during pulping and bleaching, owing to the strong hydrogen bonding in the cellulose-hemicellulose system. $^{23}$ Glucose, another major monosaccharide, was detected in both pulps. This finding was attributed to the low molecular weight of the cellulose fractions, which had been degraded into glucose during analysis. ${ }^{24}$

\section{Crystallinity index}

${ }^{13} \mathrm{C}$ CP/MAS NMR spectroscopy was employed to determine the CrI of the two pulps. In general, crystalline cellulose I is a mixture of two distinct structures: triclinic cellulose $\mathrm{I}_{\alpha}$ and monoclinic cellulose $I_{\beta}$. The influence of the magnetic field from the NMR instrument on the supramolecular structure of cellulose revealed well-resolved resonances for the crystalline and amorphous parts of C-4 and C-6 signals. ${ }^{25}$ Based on previous literature, the C-4 and C-6 signals were suitable for crystallinity estimation for cellulose I, and cellulose II or mixtures of cellulose I and II, respectively. ${ }^{5,26}$ Figure 1 shows the CP-MAS ${ }^{13} \mathrm{C}$ NMR spectra of EFB and kenaf core pulps. The peak at approximately $\delta 102-109$ ppm was attributed to $\mathrm{C}-1$, whereas the peak at approximately $\delta 80-91 \mathrm{ppm}$ was attributed to the $\mathrm{C}-4$ of cellulose. The signal from $\delta 69-79 \mathrm{ppm}$ is composed of resonances from C-2, C-3 and C-5 and the signal from $\delta 59-67 \mathrm{ppm}$ was assigned to C-6. Figure 2 (a) and (b) shows the spectral fitting of the C-4 region. Based on the manual deconvolution of the $\mathrm{C}-4$ resonance, the $\mathrm{CrI}$ of $49.4 \%$ for EFB was slightly lower than the CrI of $51.5 \%$ for kenaf core pulp. The values from the peak fitting evaluation for EFB and kenaf core pulps were $48.8 \%$ and $51.8 \%$, respectively, which are very close to the values gained from manual integration, where hemicellulose was considered.

Table 1

Monosaccharide contents detected in cellulose pulps

\begin{tabular}{lcc}
\hline & EFB pulp $\left(\mu \mathrm{g} \mathrm{mg}^{-1}\right)$ & Kenaf core pulp $\left(\mu \mathrm{g} \mathrm{mg}^{-1}\right)$ \\
\hline Glucose & 53.62 & 46.12 \\
Xylose & 50.66 & 32.43 \\
Mannose & 1.39 & - \\
Total & 105.67 & 78.55 \\
\hline
\end{tabular}

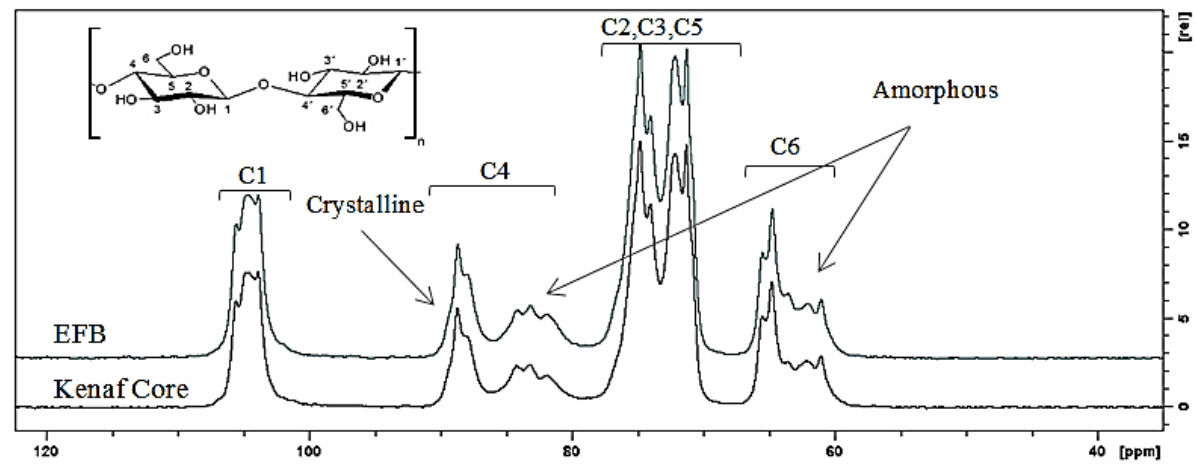

Figure 1: CP-MAS ${ }^{13} \mathrm{C}$ NMR spectra of EFB and kenaf core pulps 

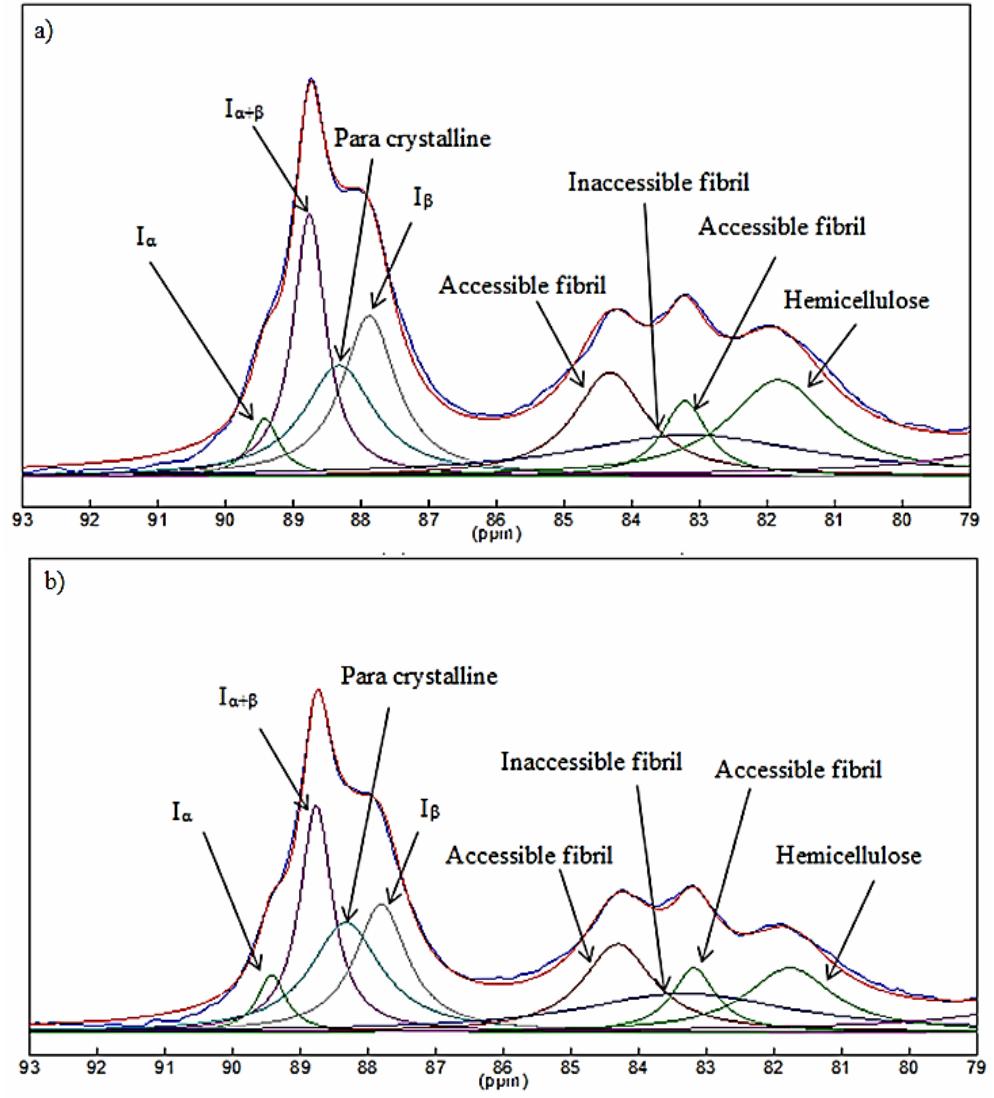

Figure 2: Spectral fitting (deconvolution) of the C-4 region in CP-MAS ${ }^{13} \mathrm{C}$ NMR spectra: a) EFB pulp and b) kenaf core pulp

Table 2

Chemical shift regions used for spectral fitting of the $\mathrm{C}-4$ region

\begin{tabular}{lcccccc}
\hline & \multicolumn{3}{c}{ EFB bleached pulp } & \multicolumn{3}{c}{ Kenaf core bleached pulp } \\
\cline { 2 - 7 } & $\begin{array}{c}\delta \\
(\mathrm{ppm})\end{array}$ & $\begin{array}{c}\text { Width } \\
(\mathrm{ppm})\end{array}$ & $\begin{array}{c}\text { Integral } \\
(\%)\end{array}$ & $\begin{array}{c}\delta \\
(\mathrm{ppm})\end{array}$ & $\begin{array}{c}\text { Width } \\
(\mathrm{ppm})\end{array}$ & $\begin{array}{c}\text { Integral } \\
(\%)\end{array}$ \\
\hline $\mathrm{I}_{\alpha}$ & 89.43 & 0.51 & 3.1 & 89.43 & 0.51 & 3.6 \\
$\mathrm{I}_{\alpha+\beta}$ & 88.77 & 0.58 & 15.8 & 88.77 & 0.59 & 16.6 \\
$\mathrm{I}_{\beta}$ & 87.88 & 0.98 & 15.8 & 87.81 & 0.94 & 14.8 \\
Paracrystalline & 88.33 & 1.27 & 14.1 & 88.33 & 1.27 & 16.7 \\
Accessible fibril surface & 84.32 & 1.30 & 13.6 & 84.30 & 1.27 & 13.7 \\
Accessible fibril surface & 83.21 & 0.81 & 6.2 & 83.18 & 0.78 & 6.3 \\
Inaccessible fibril surface & 83.13 & 4.40 & 15.0 & 83.33 & 3.88 & 16.3 \\
Hemicellulose & 81.83 & 1.82 & 16.4 & 81.76 & 1.56 & 12.0 \\
\hline
\end{tabular}

Table 2 shows the detailed assignment of the signals. The two $\mathrm{I}_{\alpha}$ and $\mathrm{I}_{\beta}$ allomorphs provide two different ${ }^{13} \mathrm{C}$ shifts for $\mathrm{C}-4$, according to the organization and orientation of the corresponding cellulose chain. ${ }^{27}$ For both EFB and kenaf core pulp, $\mathrm{I}_{\alpha}$ was detected at $\delta 89.43 \mathrm{ppm}$. However, $\mathrm{I}_{\beta}$ was detected at $\delta 87.88 \mathrm{ppm}$ and $87.81 \mathrm{ppm}$ for EFB core pulp and kenaf core pulp, respectively. $\mathrm{I}_{\beta}$ was more prominent than $\mathrm{I}_{\alpha}$ in both EFB core pulp and kenaf core pulp. During the pulping process, chemicals and heat cause the unstable $\mathrm{I}_{\alpha}$ to be converted to the more stable $\mathrm{I}_{\beta}{ }^{28}$ Another four peaks were resolved via spectra fitting at the amorphous region of C-4 at approximately $\delta 81$ $84 \mathrm{ppm}$, which corresponds to accessible fibril surfaces, inaccessible fibril surfaces and hemicellulose. ${ }^{29}$ From the integral percentage in Table 4, bleached kenaf pulp had higher amounts 
of accessible fibrils and inaccessible fibrils, which were $20 \%$ and $16.3 \%$, respectively. According to previous work, ${ }^{30}$ the surfaces of accessible fibrils easily get in contact with water, while inaccessible fibrils are water-inaccessible, formed because of interior distortion or aggregation of fibrils. ${ }^{31}$ Both accessible fibrils and inaccessible fibrils were highly influenced by the dissolution of bleached pulps. ${ }^{30}$ A hemicellulose signal was also obtained from these spectra fitting analyses. Hemicellulose detected in EFB bleached pulp $(16.4 \%)$ was higher than that in kenaf bleached pulp $(12 \%)$.

\section{Molecular weight distribution and solubility}

Figure 3 illustrates the MWD of EFB and kenaf core pulps. Both chromatograms show a monomodal cellulose peak, with a shoulder at approximately $\log \mathrm{M}_{\mathrm{w}} 4.5$ to $\log \mathrm{M}_{\mathrm{w}}$ 5, originating from hemicelluloses or lowmolecular-weight cellulose fractions, which have been identified in monosaccharide analysis. The weight average molecular weights $\left(\mathrm{M}_{\mathrm{w}}\right)$ of EFB and kenaf core pulps were $4.76 \times 10^{5} \mathrm{~g} \mathrm{~mol}^{-1}$ and $3.31 \times 10^{5} \mathrm{~g} \mathrm{~mol}^{-1}$, respectively (Table 3 ). This result shows agreement with the trend observed by Baharin et al., ${ }^{32}$ who reported that EFB pulp has a higher molecular weight than kenaf core pulp based on Ubbelohde viscometer measurements. The number average molecular weight $\left(\mathrm{M}_{\mathrm{n}}\right)$ of EFB pulp $\left(1.27 \times 10^{5}\right)$ is higher than that of kenaf core pulp $\left(1.07 \times 10^{5}\right)$. EFB pulp showed a slightly higher dispersity $(\bigoplus=$ 3.78), and consequently, provides a broader distribution than kenaf core pulp $(Đ=3.08)$. As shown in Table 3, the amounts of carboxyl group content in EFB pulp and kenaf core pulp were of $20.67 \mu \mathrm{mol} \mathrm{g}{ }^{-1}$ and $30.86 \mu \mathrm{mol} \mathrm{g}{ }^{-1}$, respectively. The difference in carboxyl group amounts was due to the variation in biomass and its purity. Each biomass contains different amounts of hemicellulose, which is a major contributor to the amounts of carboxyl groups in the form of uronic acid moieties. ${ }^{33,34}$ However, these amounts reflect a higher number of hemicellulose and are associated with the oxidation of C-6 hydroxyl. During bleaching, the hydroxyl groups at C-6 of cellulose were converted to carboxylic acids. ${ }^{35}$ Because of the variation in biomass, EFB and kenaf core pulps behaved differently during the bleaching process, which consequently led to different amounts of the carboxyl group. The carboxyl group is very sensitive and tends to degrade in an alkaline environment, which consequently affects the dissolving process of pulp and the formation of $\mathrm{CM}^{36}$

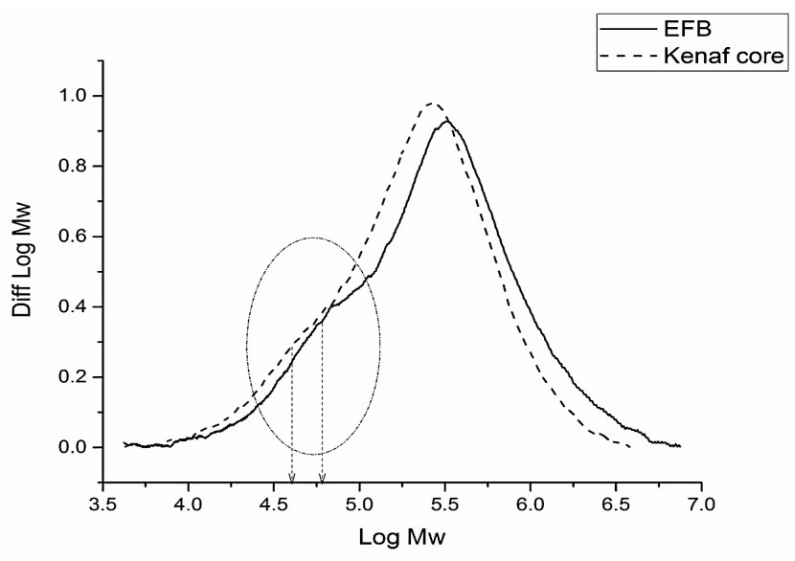

Figure 3: Molecular weight distribution of cellulose pulps from kenaf core and EFB; the shoulder at approximately Log $\mathrm{M}_{\mathrm{w}} 4.5$ to $\log \mathrm{M}_{\mathrm{w}} 5$ arises from hemicellulose or low-molecular-weight cellulose fractions

Table 3

Molecular weight distribution of EFB and kenaf core pulps

\begin{tabular}{lcccc}
\hline Pulp & $\begin{array}{c}\text { Mw } \\
\left(\mathrm{g} \mathrm{mol}^{-1}\right)\end{array}$ & $\begin{array}{c}\text { Mn } \\
\left(\mathrm{g} \mathrm{mol}^{-1}\right)\end{array}$ & $\begin{array}{c}\text { Dispersity } \\
\text { Đ }\end{array}$ & $\begin{array}{c}\text { Carboxyl group content } \\
\left(\mu \mathrm{mol} \mathrm{g}^{-1}\right)\end{array}$ \\
\hline EFB & $4.76 \times 10^{5}$ & $1.27 \times 10^{5}$ & 3.73 & 20.67 \\
Kenaf core & $3.31 \times 10^{5}$ & $1.07 \times 10^{5}$ & 3.08 & 30.86 \\
\hline
\end{tabular}


Cellulosic pulp

Table 4

Weight percentages of cellulosic pulps in different molecular weight regions

\begin{tabular}{lcc}
\hline DP & Kenaf core $(\%)$ & EFB $(\%)$ \\
\hline$<100$ & 1.51 & 1.08 \\
$100-200$ & 4.34 & 3.10 \\
$200-2000$ & 59.83 & 51.45 \\
$>2000$ & 34.3 & 44.35 \\
\hline
\end{tabular}

Table 5

Solubility of cellulosic pulps in $\mathrm{NaOH} /$ urea solvent

\begin{tabular}{lc}
\hline Pulp & Solubility (\%) \\
\hline Kenaf core & $73.10 \pm 0.13$ \\
EFB & $32.95 \pm 0.52$ \\
\hline
\end{tabular}

Table 4 shows the percentage contents of four different molecular weight regions (degree of polymerization (DP) ranges), which are often utilized to describe the differences in the cellulosic pulps. The DP represents the number of AGUs in a cellulose chain. The DP was obtained by splitting the MWD at the respective DP range and auto-calculated using software. The DP values of the EFB pulp and the kenaf core pulp, which are below 200 , were $4.18 \%$ and $5.85 \%$, respectively. This result represented a mixture of hemicellulose and low-molecular-weight cellulose. ${ }^{37-39}$ The kenaf core pulp consists of a higher DP of 200-2000, with almost $60 \%$ compared with the EFB pulp, which is only $51 \%$. However, EFB pulps exhibit a 10\% higher DP value of $>2000$ than the kenaf core pulp, which shows that EFB has not only a higher $\mathrm{M}_{\mathrm{w}}$, but also a higher DP than kenaf core pulp. During bleaching, cellulose tends to slightly depolymerize because of the utilization of sodium chlorite and acetic acid in the bleaching procedure. ${ }^{40}$ Kenaf pulp is extensively degraded after it is bleached, compared with EFB pulp. ${ }^{32}$ This finding suggests that EFB pulp can be restrained from severe depolymerization due to a high DP. The difference in plant species may be another factor influencing the different weight percentages in the respective regions. ${ }^{41}$

Cellulose hardly dissolves in water and most organic solvents. However, the solubility data (Table 5) shows that the solubility of EFB and kenaf core pulps, with $33 \%$ and $73 \%$, respectively, in $\mathrm{NaOH} / \mathrm{urea}$ is possible. This solubility occurred due to (i) the breakdown of intermolecular hydrogens at low temperature $(<10$ ${ }^{\circ} \mathrm{C}$ ), (ii) $\mathrm{NaOH}$ hydration and interaction with cellulose, and (iii) urea hydration prevented agglomeration of cellulose. $^{42}$ Kenaf was accessible to dissolve in $\mathrm{NaOH} / \mathrm{urea}$ due to its high content of carboxyl group, and hence, enhanced the swelling of cellulose. Nonetheless, EFB pulp showed lower solubility than kenaf core pulp, because of its higher molecular weight and DP.

\section{Morphological analysis}

Membranes with two thicknesses $(0.04 \mathrm{~mm}$ and $0.07 \mathrm{~mm}$ ) were prepared to determine the effect of thickness on the morphological properties. Figure 4 ( $\mathrm{a}$ and $\mathrm{b}$ ) shows the crosssection morphology of CM0.04 and CM0.07 prepared from kenaf core bleached pulp. The morphological analysis of the EFB membrane is not shown because it was not successfully formed because of the solubility limitation. Both crosssection images showed inhomogeneous pore distribution. From ImageJ, the pore size for CM0.07 ranges from 1 to $2000 \mu \mathrm{m}$, while the pore size of CM0.04 mm ranges from 1 to 6500 $\mu \mathrm{m}$. The use of $\mathrm{H}_{2} \mathrm{SO}_{4}$ produced a membrane with small pore sizes. ${ }^{43}$ However, in the present study, this result was due to the longer coagulation time. CM0.07 was detached from the glass slide after 15 min, while CM0.04 was detached from the glass slide after $5 \mathrm{~min}$. This difference allowed greater reformation of new hydrogen bonding among cellulose molecules in CM0.07 during the coagulation process, ${ }^{11,44}$ and a $\mathrm{CM}$ with small pores was formed.

\section{Tensile and transparency test}

Table 6 shows the tensile and transparency properties of CM0.04 and CM0.07. The tensile properties of CM0.07 were higher than those of CM0.04. CM0.07 had a tensile strength of 33.48 $\mathrm{MPa}$, with a maximum load of $25.55 \mathrm{~N}$ and $8 \%$ elongation. The excellent tensile properties of 
CM0.07 were due to its smaller pore size and rigid structure. ${ }^{45}$ In addition, the tensile properties could also be due to the presence of the hemicellulose that remained and was entangled in the pulp. Hemicellulose promotes cellulose alignment and acts as a plasticizer, which consequently enhanced the mechanical properties of the $\mathrm{CM}^{46}$ However, the presence of the hemicellulose membrane and low pore sizes caused the scattering of the incident light, which weakened the membrane and led to low transparency for CM0.07 (20.54\%). ${ }^{47}$
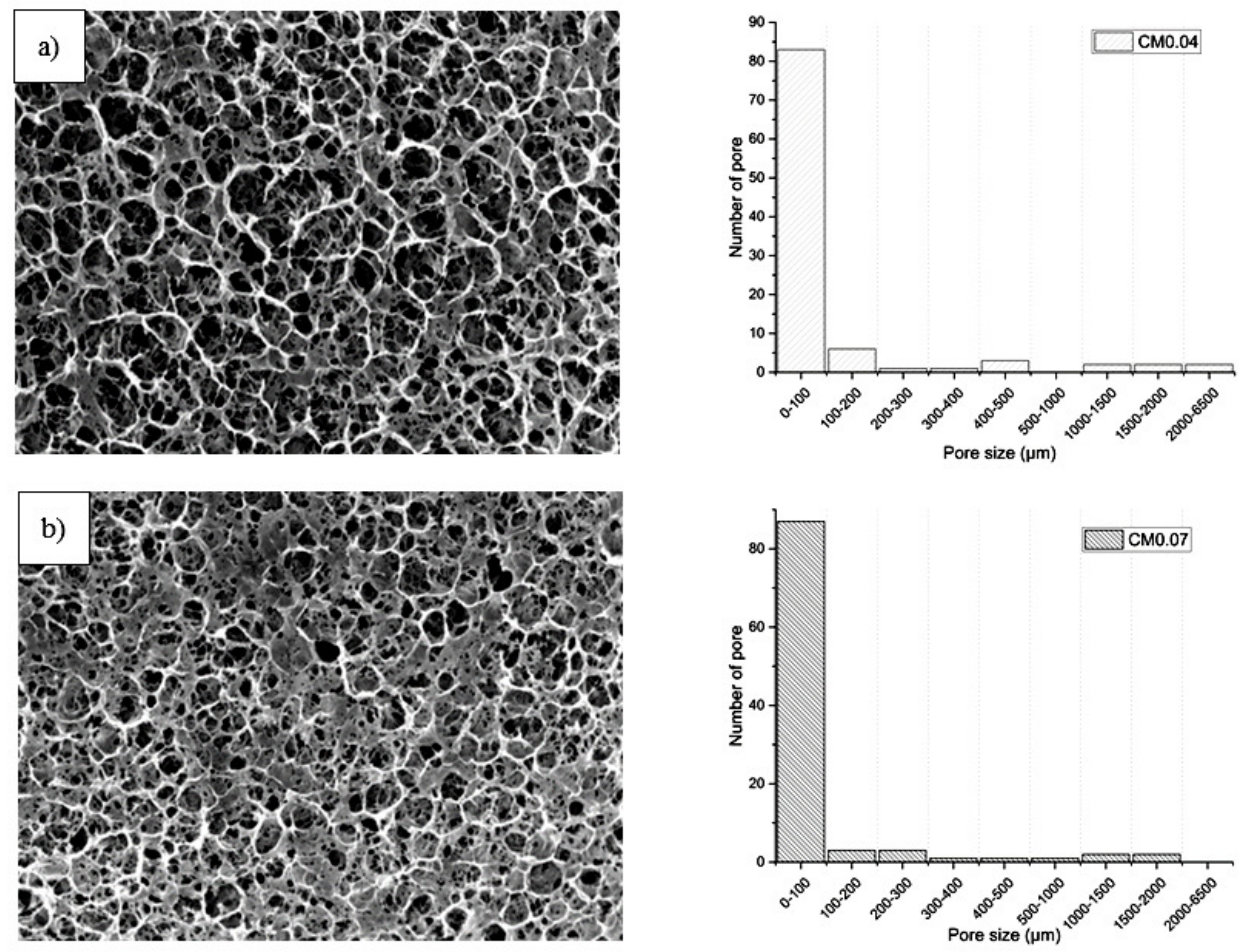

Figure 4: Distribution of pores of a) CM0.04 and b) CM0.07 - significantly affected by membrane thickness

Table 6

Tensile and transparency properties of $\mathrm{CM}$ at two different thicknesses

\begin{tabular}{lcc}
\hline Properties & CM0.04 & CM0.07 \\
\hline Tensile strength (MPa) & 23.78 & 33.48 \\
Maximum load (N) & 10.18 & 25.55 \\
Elongation (\%) & 6.50 & 8.03 \\
Young's modulus, E (MPa) & 1288.38 & 2138.52 \\
Transparency (\%) & 44.48 & 20.54 \\
\hline
\end{tabular}

\section{CONCLUSION}

In this study, we discovered that kenaf core and EFB bleached pulps behaved differently in the same bleaching procedure. The low molecular weight and DP, as well as the high accessibility of fibril surfaces and carboxyl group of kenaf core bleached pulp allowed the production of membranes with reasonable mechanical properties. EFB had a longer polymer chain, which limited dissolution and membrane formation. The membrane thickness had a crucial effect on the membrane properties, such as tensile 
strength and transparency. The CM0.07 membrane had a smaller pore size than CM0.04, which enhanced the tensile properties and reduced the transparency of the membrane.

ACKNOWLEDGEMENTS: The authors would like to acknowledge the financial support of the Malaysian Ministry of Higher Education via FRGS/1/2018/STG07/UKM/01/1, DIP-2018-033, Erasmus Mundus ALFABET for supporting the mobility at Christian-Doppler Laboratory of the University of Natural Resources and Life Sciences (BOKU), Vienna, and MyBrain15.

\section{REFERENCES}

1 B. Norizan, N. U. R. Sauta, S. N. A. Syed Hashim, S. Zakaria, M. Daud et al., Cellulose Chem. Technol., 53, $1001 \quad$ (2019), https://doi.org/10.35812/CelluloseChemTechnol.2019. 53.98

2 J. Gominho, A. Lourenço, D. Neiva, L. Fernandes, M. Amaral et al., Eur. J. Wood Wood Prod., 74, 101 (2016), https://doi.org/10.1007/s00107-015-0965-2

3 M. S. Jahan, S. Rawsan, D. A. Nasima Chowdhury and A. Al-Maruf, BioResources, 3, 1359 (2008), https://ojs.cnr.ncsu.edu/index.php/BioRes/article/view/ BioRes_03_4_1359_Jahan_RNA_Atl_Pulping_Dissol V_Jute

E. Hafemann, R. Battisti, D. Bresolin, C. Marangoni and R. A. F. Machado, Waste Biomass Valorif., (2020), https://doi.org/10.1007/s12649-02000937-2

5 X. Zhu, Y. Dai, C. Wang and L. Tan, Contributions to Tobacco Research, 27, $126 \quad$ (2016), https://doi.org/10.1515/cttr-2016-0014

6 N. Kruer-Zerhusen, B. Cantero-Tubilla and D. B. Wilson, $\quad$ Cellulose, 25, $37 \quad$ (2018), https://doi.org/10.1007/s10570-017-1542-0

A. Potthast, S. Radosta, B. Saake, S. Lebioda, T. Heinze et al., Cellulose, 22, 1591 (2015), https://doi.org/10.1007/s10570-015-0586-2

8 J. Cai, L. Wang and L. Zhang, Cellulose, 14, 205 (2007), https://doi.org/10.1007/s10570-007-9106-3

9 N. A. Azahari, S. Gan, S. Zakaria, H. Kaco and S. Moosavi, Cellulose Chem. Technol., 52, 201 (2018), http://www.cellulosechemtechnol.ro/pdf/CCT34(2018)/p.201-207.pdf

10 N. S. N. Mazlan, S. Zakaria, S. Gan, C. C. Hua and K. W. Baharin, CERNE, 25, 18 (2019), http://dx.doi.org/10.1590/01047760201925012586

11 H. Kaco, S. Zakaria, C. H. Chia and L. Zhang, BioResources, 9, $2167 \quad$ (2014), https://doi.org/10.15376/biores.9.2.2167-2178

12 F. Khili, J. Borges, P. L. Almeida, R. Boukherroub and A. D. Omrani, Waste Biomass Valorif., 10, 1913 (2019), https://doi.org/10.1007/s12649-018-0202-4
13 C. Das and K. A. Gebru, Journal of The Institution of Engineers (India): Series E, 98, 91 (2017), https://doi.org/10.1007/s40034-017-0104-1

14 O. V. Alekseeva, A. N. Rodionova, N. A. Bagrovskaya, A. V. Agafonov and A. V. Noskov, Arabian J. Chem., 12, $398 \quad$ (2019), https://doi.org/10.1016/j.arabjc.2015.07.011

15 Y. C. Ching and T. C. Ng, BioResources, 9, 6373 (2014),

https://ojs.cnr.ncsu.edu/index.php/BioRes/article/view/ BioRes09_4_6373_Ching_Cellulose_Oil_Palm_Fiber

16 I. Kamal, M. Z. Thirmizir, G. Beyer, M. J. Saad, N. A. A. Rashid et al., J. Sci. Technol., 6, 41 (2014), https://publisher.uthm.edu.my/ojs/index.php/JST/articl e/view/796

17 R. H. Newman, Holzforschung, 58, 91 (2004), https://doi.org/10.1515/HF.2004.012

18 D. Massiot, F. Fayon, M. Capron, I. King, S. L. Calvé et al., Magn. Resonan. Chem., 40, 70 (2002), https://doi.org/10.1002/mrc.984

19 J. Röhrling, A. Potthast, T. Rosenau, T. Lange, G. Ebner et al., Biomacromolecules, 3, 959 (2002), https://doi.org/10.1021/bm020029q

20 A. Potthast, T. Rosenau, P. Kosma, A.-M. Saariaho and T. Vuorinen, Cellulose, 12, 43 (2005), https://doi.org/10.1023/B:CELL.0000049347.01147.3d 21 T. Y. Ying, L. K. Teong, W. N. W. Abdullah and L. C. Peng, Procedia Environ. Sci., 20, 328 (2014), https://doi.org/10.1016/j.proenv.2014.03.041

22 R. Ibrahim, Oil Palm Bull., 44, 19 (2002), https://www.cabdirect.org/cabdirect/abstract/20023162 448

23 X. Zhang, W. Yang and W. Blasiak, Energ. Fuels, 25, 4786 (2011), https://doi.org/10.1021/ef201097d

24 F. Zeinaly, A. Saraeian, K. Gabov and P. Fardim, Cellulose Chem. Technol., 51, 45 (2017), http://www.cellulosechemtechnol.ro/pdf/CCT12(2017)/p.45-53.pdf

${ }^{25}$ G. Zuckerstätter, G. Schild, P. Wollboldt, T. Röder, H. Weber et al., Lenzinger Berichte, 87, 38 (2009), https://www.semanticscholar.org/paper/Theelucidation-of-cellulose-supramolecular-by13CZuckerstaetterSchild/c27d9881db5e023aba0bbc3a e76f22e158863349

26 A. Mittal, R. Katahira, M. E. Himmel and D. K. Johnson, Biotechnol. Biofuels, 4, 1 (2011), https://doi.org/10.1186/1754-6834-4-41

27 H. Kono and Y. Numata, Cellulose, 13, 317 (2006), https://doi.org/10.1007/s10570-005-9025-0

28 S. Maunu, T. Liitiä, S. Kauliomäki, B. Hortling and

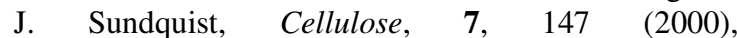
https://doi.org/10.1023/A:1009200609482

${ }^{29}$ K. Wickholm, P. T. Larsson and T. Iversen, Carbohyd. Res., 312, 123 (1998), https://doi.org/10.1016/S0008-6215(98)00236-5

${ }^{30}$ V. Chunilall, T. Bush and P. T. Larsson, in "Fundamental Aspects", edited by T. V. D. Ven and L. Godbout, IntechOpen, 2013, pp. 69-90, 
https://www.intechopen.com/books/cellulosefundamental-aspects

31 E. L. Hult, P. T. Larsson and T. Iversen, Polymer, 42, 3309 (2001), https://doi.org/10.1016/S00323861(00)00774-6

32 K. W. Baharin, S. Zakaria, A. V. Ellis, N. Talip, H. Kaco et al., Sains Malaysiana, 47, 377 (2018), http://www.ukm.my/jsm/pdf_files/SM-PDF-47-22018/UKM\%20SAINSMalaysiana\%2047(02)Feb\%20 2018\%2020.pdf

33 W. Judiawan, Y. Sudiyani and E. Nurnasari, Indonesian J. Appl. Chem., 21, 14 (2019), https://doi.org/10.14203/jkti.v21i1.412

34 S. Palamae, P. Dechatiwongse, W. Choorit, Y. Chisti and P. Prasertsan, Carbohyd. Polym., 155, 491 (2017), https://doi.org/10.1016/j.carbpol.2016.09.004

35 L. C. A. Barbosa, C. R. A. Maltha, A. J. Demuner, C. M. Cazal, E. L. Reis et al., Bioresources, 8, 1043 (2013),

https://ojs.cnr.ncsu.edu/index.php/BioRes/article/view/ BioRes_08_1_1043_Barbosa_Quantification_Carboxy 1_Groups

${ }^{3 \overline{6}}$ J. Perrin, F. Pouyet, C. Chirat and D. Lachenal, Bioresources, $\quad 9, \quad 7299 \quad$ (2014), http://stargate.cnr.ncsu.edu/index.php/BioRes/article/vi ew/BioRes_09_4_7299_Perrin_Carbonyl_Carboxyl_G roups_Cellulosic_Pulps

37 T. A. Gulbrandsen, I. A. Johnsen, M. T. Opedal, K. Toven, K. Øyaas et al., Cellulose Chem. Technol., 49, 117

http://www.cellulosechemtechnol.ro/pdf/CCT2(2015)/ p.117-126.pdf
38 J. Röhrling, A. Potthast, T. Rosenau, T. Lange, A. Borgards et al., Biomacromolecules, 3, 969 (2002), https://doi.org/10.1021/bm020030p

39 A. Potthast, J. Röhrling, T. Rosenau, A. Borgards, H. Sixta et al., Biomacromolecules, 4, 743 (2003), https://doi.org/10.1021/bm025759c

40 C. A. Hubbell and A. J. Ragauskas, Bioresour. Technol., $\quad \mathbf{1 0 1}, \quad 7410 \quad$ (2010), https://doi.org/10.1016/j.biortech.2010.04.029

41 G. Siqueira, J. Bras and A. Dufresne, Polymers, 2, 728 (2010), https://doi.org/10.3390/polym2040728

42 M. G. Walters, A. D. Mando, W. Matthew Reichert, C. W. West, K. N. West et al., RSC Adv., 10, 5919 (2020), https://doi.org/10.1039/c9ra07989k

43 L. Zhang, Y. Mao, J. Zhou and J. Cai, Ind. Eng. Chem. Res., 44, $522 \quad$ (2005), https://doi.org/10.1021/ie0491802

44 S. Zhang, F. X. Li and J. Y. Yu, Cellulose Chem. Technol., $\quad 45, \quad 593 \quad$ (2010), http://www.cellulosechemtechnol.ro/pdf/CCT45,910(2011)/p.593-604.pdf

45 N. A. Azahari, S. Gan, S. Zakaria, H. Kaco and S. Moosavi, Cellulose Chem. Technol., 52, 201 (2018), http://cellulosechemtechnol.ro/pdf/CCT34(2018)/p.201-207.pdf

46 J. H. Chen, Y. Guan, K. Wang, F. Xu and R. C. Sun, Cellulose, 22, $1505 \quad$ (2015), https://doi.org/10.1007/s10570-015-0608-0

${ }_{47}$ Y. Wang, L. Yuan, H. Tian, L. Zhang and A. Lu, J. Membrane Sci., $\quad \mathbf{5 8 5}, \quad 99 \quad$ (2019), https://doi.org/10.1016/j.memsci.2019.04.059 